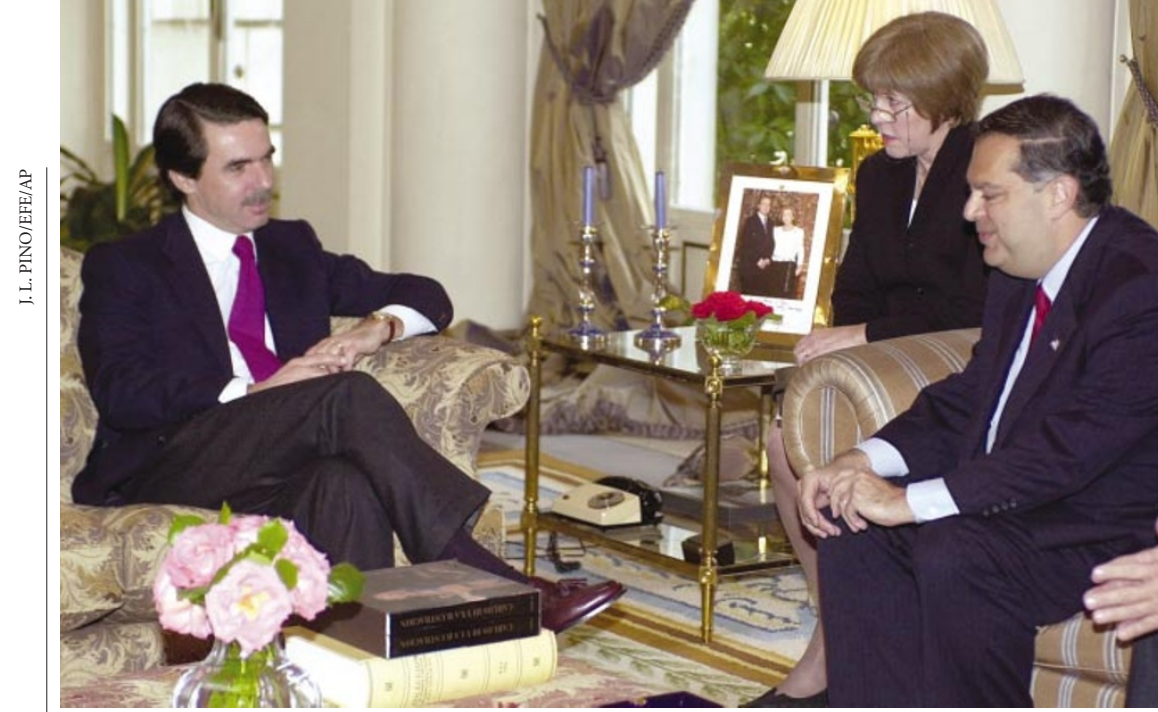

Spencer Abraham (right) meets with Prime Minister José María Aznar during his visit to Spain.

\title{
US support for Spain triggers unease over fusion project
}

Geoff Brumfiel, Washington,

and Declan Butler, Paris

The US energy secretary has come close to endorsing Spain's bid to host a huge international fusion experiment — snubbing French plans for the project and unsettling delicate European site negotiations.

Spencer Abraham visited Madrid on 1 May to discuss Spain's bid to host ITER, the planned US\$5-billion project to build an experimental magnetic-fusion reactor.

After meeting with high-level Spanish officials, Abraham held a press conference at which he described the proposed site at Vandellòs near Barcelona as "very impressive". $\mathrm{He}$ emphasized that the trip was the first visit he had made with regard to ITER's siting, saying: "I hope that demonstrates the level of interest we have [in] the proposal Spain has offered," (see www.embusa.es/ ratoabraham.html).

$\mathrm{He}$ added that when President Bush brought the United States back into ITER earlier this year he was aware of Spain's proposal. "He asked me to travel to Madrid to learn more" about the site and "to make sure that the United States would give it very serious consideration", Abraham said.

Abraham's visit - his first to Spain preceded a meeting of the European Council of Ministers, which agreed to select a single European site for the reactor this year.

Spanish and American officials deny that the United States is meddling in Europe's affairs. But European researchers say that they detect an attempt by the United States to reward Spain for its cooperation in the occupation of Iraq, which France opposed.

ITER is an international collaboration between the European Union, Canada, Japan, Russia, China and the United States. At present, there are four proposed sites for the facility: Clarington in Canada, Rokkasho in Japan, Cadarache in France and Vandellòs.
Jeanne Lopatto, a spokeswomen for the US energy department, denies that Abraham is playing favourites. "He did not by any means endorse one site over another," she says. Last week, the Spanish economics minister, Rodrigo Rato, similarly dismissed as "simplistic" the idea that Spain is being rewarded for its cooperation on Iraq.

Christian Poncet, who is coordinating the French bid to host ITER, plays down Abraham's comments. "I think that Mr Abraham will also visit Clarington, Rokkasho, and I hope he will visit Cadarache," he says.

And even if the United States were to express a preference, that need not be perceived as meddling in European affairs, suggests Murray Stewart, who heads ITER Canada. The preferences of other ITER partners are "reasonable criteria" for choosing a domestic site, Stewart says.

An official at the European Commission disagrees, saying that the selection of a European site is an internal matter. Abraham's remarks are "at the very least surprising", he adds.

Other officials in Europe are nervous over what they see as the US administration's agenda infringing on their decision-making process. "The indications we've had from the State Department is that the United States would stay neutral," says one German official. Another senior European fusion researcher, who didn't want to be named, says that many in his community take a "dim view” of the energy secretary's actions.

The European Commission is now undertaking a technical assessment of the two sites, probably to be led by David King, chief scientific adviser to British Prime Minister Tony Blair. King visited Spain on 9 May and told reporters he found Vandellòs "very attractive". But he added: "Right now, I'm not sure which site is better."
Medical council pins hopes on public advocate of science

Jim Giles, London

Leading neuroscientist Colin Blakemore has been chosen to run Britain's main biomedical research agency, the Medical Research Council (MRC).

Blakemore's assertive personality, which colleagues say he brings to all aspects of his work, is likely to be tested to the full at the London-based council. The organization that he inherits from George Radda, the molecular cardiologist who has been the MRC's chief executive since 1996, has been facing a barrage of criticism lately from the community it funds (see Nature 422, 461; 2003).

Currently head of the Centre for Cognitive Neuroscience at the University of Oxford, Blakemore is well respected for his research on the development of the visual system. He also has a strong track record of promoting science with the general public.

Blakemore, who takes over from Radda in October, says that he will investigate whether the MRC grant applications process could be made more open and its paperwork streamlined. He also says he would like to see whether the council can help to increase the credit that researchers get for taking part in science communication. "Young scientists need to get more professional reward for these activities," he says.

Blakemore is often in the media spotlight. During the mid-1990s he was singled out by animal-rights campaigners and received numerous death threats. A letter bomb was sent to his house, although the device did not explode. The experiences prompted Blakemore to become an unofficial spokesman for the use of animals in research - a role he says he will continue to play after he takes up his new position.

Colleagues of Blakemore expect him to tackle this and other issues with his

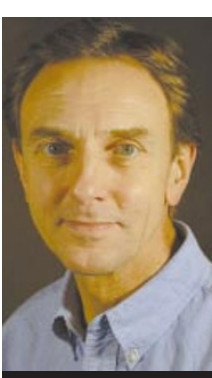

Colin Blakemore: energetic science communicator. usual, and sometimes fiery, dynamism. "He can get quite heated," notes Andrew Lumsden, a developmental neurobiologist at King's College London. But Lumsden, like other researchers contacted by Nature, says that such passion will work in the council's favour. 